\title{
Combined use of the Kozani-8 geothermal water, some thermal and economical calculations
}

\author{
Nevton Kodhelaj \\ Energy resources department \\ Faculty of Geology and Mining, Polytechnic University \\ Tirane, Albania \\ nevtonkodheli@yahoo.com \\ Bashkim Çela \\ Energy resources department \\ Faculty of Geology and Mining, Polytechnic University \\ Tirane, Albania \\ celabashkim@yahoo.com \\ Spiro Thodhorjani \\ Faculty of Geology and Mining, Polytechnic University \\ Energy resources department \\ Faculty of Geology and Mining, Polytechnic University \\ Tirane, Albania \\ sthodhorjani@yahoo.com
}

\author{
Aida Bode \\ Department of mineral resources engineering \\ Faculty of Geology and Mining, Polytechnic University \\ Tirane, Albania \\ boaal@yahoo.com \\ Riza Aleti \\ Energy resources department \\ Tirane, Albania \\ rial_99@yahoo.com \\ Rajmonda Mumajesi \\ Department of Finance \\ Faculty of Geology and Mining, Polytechnic University \\ Tirane, Albania \\ mmumajesi@yahoo.com
}

\begin{abstract}
Albania is relatively rich with low up to the middle enthalpy, geothermal resources. Their temperature varies from $34^{\circ} \mathrm{C}$ up to $65.5^{\circ} \mathrm{C}$ to Kozani -8 , the most important among the Albanian geothermal wells. The geographical position of the well, placed in the middle of a village, very close to the corridor 8 , are the basic parameters on choosing these waters for our designs and calculations. The design provides the cascade and integral use, but not only. It also provide the electricity generations, through a hybrid system. The economic analyses, based on the NPV calculations, shows that this resource is completely competitive, and is unjustified it's further "waste". Despite the fact that the investment is too high (over 5.5 million Euro), it is completely feasible. It will also help on improving the living standards for the local community.
\end{abstract}

Keywords:Geothermal, Kozani-8, pool, temperature, cascade, heat exchanger, economics.

\section{INTRODUCTION}

The Ishmi-Kruja geothermal zone is close to the "Mother Teresa" international airport. It is also next to the Kruja historical city, the wonderful Adriatic Sea beaches \& Lake of Ohrid. The demonstrative geothermal center, with the cascade and integral use, but also combined with the solar panels (hybrid system), is designed for the Kozani-8 well waters. The choice had been made because of its temperature, on the value of $65.5^{\circ} \mathrm{C}$, and yield $10 \mathrm{l} / \mathrm{s}$. In the aquifer top of the well trunk the water is $80^{\circ} \mathrm{C}$. Hot water has salinity of (4.6-19.3) $\mathrm{g} / \mathrm{l}$. actually all these waters are "wasted": they flows directly to a creek, meaning high economical loses. Among different processes of the cascade, will be released $\mathrm{CO}_{2}$ and $\mathrm{H}_{2} \mathrm{~S}$, which will be used for food products (conservation) and medical purposes. The hybrid system, combing of the middle enthalpy geothermal waters, with the solar panels, based on the fact that the Albanian climate allow such a thing (there are more than
280 sunny days on the area), will improve the economic efficiency of the project.

\section{THE GEOLOGICAL STRUCTURE OF THE REGION}

The Kruja Geothermal Zone extends for $180 \mathrm{~km}$ from the Adriatic Sea in the North and continues down to the South Eastern area of Albania and to the Konitza area in Greece [1]. Geothermal aquifer is represented by a carstified neritic carbonate formation with numerous fissures and micro fissures. Three boreholes produce hot and mineralized water: Ishmi-1/b, Kozani-8 and Galigati-2. Kozani-8 geothermal well lies on the limestone structure of Kozani, which lies about 180 $\mathrm{km}$, with a width of 4-5 km [2]. On the regional point of view, sink up to the depth of $10 \mathrm{~km}$, where they are placed above the Triassic evaporites formation [3]. In this depth the temperature reach the values of $120-150^{\circ} \mathrm{C}$. Important for this region is the presence of the tectonic, related with the evaporites formations [4]. Kozani-8 well is placed in the S-E of Tirana. The water comes from the interval 1816-1837 $\mathrm{m}$ of depth [1]. The formation temperature is $80^{\circ} \mathrm{C}$, while the pressure is 191 bars. The wellhead pressure is 12 bars, while the temperature is $65.5^{\circ} \mathrm{C}$. The mineralization is $4.6 \mathrm{~g} / \mathrm{l}$ [3], $\mathrm{pH}=7.5$; the cations $\mathrm{Ca}^{2+}=27.62 \mathrm{mg} / \mathrm{l}, \quad \mathrm{Mg}^{2+}=20.4 \mathrm{mg} / \mathrm{l}, \quad \mathrm{Na}^{+}=268.5 \mathrm{mg} / \mathrm{l}$, $\mathrm{NH}_{4}{ }^{+}=47.5 \mathrm{mg} / \mathrm{l}$; the anions $\mathrm{Cl}^{-}=270.2 \mathrm{mg} / \mathrm{l}, \mathrm{SO}_{4}{ }^{2-}=46.2 \mathrm{mg} / \mathrm{l}$ and $\mathrm{HCO}_{3}{ }^{2-}=10 \mathrm{mg} / \mathrm{l}$; the microelements $\mathrm{B}=0.00067 \mu \mathrm{g} / \mathrm{l}$.

\section{ENERGETIC RESERVES EVALUATION OF THE KOZANI LIMESTONE STRUCTURE}

Theenergetic calculation of the proposed center intent to give the results of the formation heat $\mathrm{Q}_{0}$, geothermal energy reserves $Q_{1}$, recoverable energy $E$, specific reserves $q$, energetic capacity $Q_{e}$, and annual energy use $S_{e}$ and the capacity factor $\mathrm{K}$. Their values are showed in the table 1 [5]. 
TABLE 1: THE ENERGETIC VALUES OF THE KOZANI-8 GEOTHERMAL WELL

\begin{tabular}{|c|c|c|c|c|c|c|}
\hline \multicolumn{7}{|c|}{ Energetic values of the Kozani-8 well, geothermal water } \\
\hline $\boldsymbol{Q}_{\boldsymbol{0}}$ & $\boldsymbol{Q}_{\boldsymbol{I}}$ & $\boldsymbol{E}$ & $\boldsymbol{q}$ & $\boldsymbol{Q}_{\boldsymbol{e}}$ & $\boldsymbol{S}_{\boldsymbol{e}}$ & $\boldsymbol{K}$ \\
\hline${ }_{1.0712^{*} * 10^{10} \mathrm{GJ}}$ & ${ }^{1.0712^{*}+10^{9} \mathrm{GJ}}$ & ${ }^{2.4011^{*} 10^{10} \mathrm{GJ}}$ & $39.63 \mathrm{GJ} / \mathrm{m}^{2}$ & $2.05 \mathrm{Mwah}$ & $0.39 \mathrm{TJ} /$ year & 0.006 \\
\hline
\end{tabular}

THE SCHEME FOR THE INTEGRAL, CASCADE AND HYBRID USE OF THE KOZANI-8 GEOTHERMAL WATERS

It was thought by the group of authors, that the best and more efficient way to use the geothermal waters of Kozani-8 well is the constructions of a multicenter [6]. The center will include the SPA, massage and fitness center, open and closed pools (with different sizes and temperatures), greenhouse, aquaculture cultivation pools, conference rooms etc. The center will be heated through the geothermal direct use (through the installation of the heat exchangers) [7], while for the cooling will be installed a geothermal heat pump [4]. The roof will be covered will solar panels, whose will provide the sanitary water and also a part of them, will circulate the geothermal water, increase its temperature, allowing so the electricity production (the hybrid system). This electricity will serve for the lighting system of the center (green energy). In the "Fig. 1", is showed the frontal view of the center, while in the "Fig. 2", the principal sketch of the integral, cascade and the hybrid system [7].

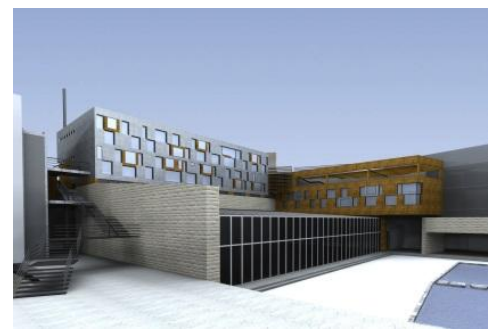

Fig.3. The Shijoni recreational center frontal view

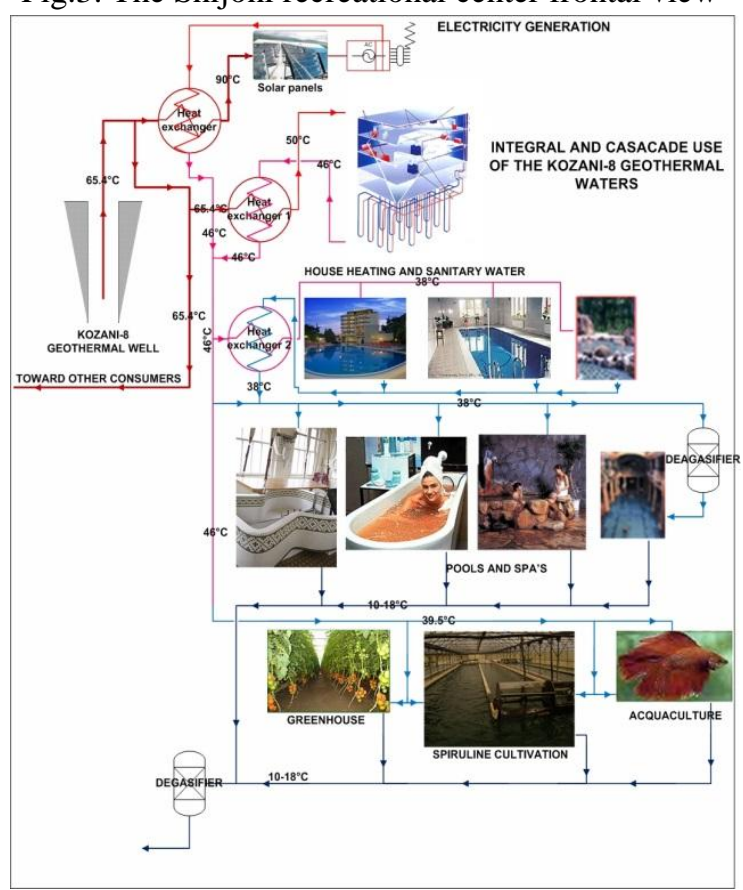

Fig.3. The principal sketch of the center

\section{HEAT LOSSES}

The proposed center will have several pools: 1 geothermal pool (designed as a natural pond, sized $10 * 8 * 0.5 \mathrm{~m}$, water temperature $38^{\circ} \mathrm{C}$-degasified); 1 open Olympic pool (sized $50 * 23 * 3 \mathrm{~m}$, water temperature $30^{\circ} \mathrm{C}$ ); 1 sweet water pool (sized $10 * 5 * 1.5 \mathrm{~m}$-escalate, water temperature $38^{\circ} \mathrm{C}$ degasified, lightly closed); 1 kids sweet water pool (sized $5 * 3 * 0.5 \mathrm{~m}$-escalate, water temperature $30^{\circ} \mathrm{C}$ ) [8]. The heat loses of the system are influenced by a number of factors including the number of the guests, their physical activity, the electrical equipment's, solar radiation, natural ventilation, thermo insulation etc. Calculation for the electrical equipment's are made based on the assumption that the maximum load, varies during the day, to avoid their supersizing. In the tables 2, 3 and 4 can be seen the results [9].

TABLE 2: THE WINTER THERMAL LOAD OF THE CENTER

\begin{tabular}{|c|c|c|c|c|}
\hline \multirow{2}{*}{ Room/environment } & \multicolumn{4}{|c|}{ WINTER } \\
\cline { 2 - 5 } & $\begin{array}{c}\text { Thermal load } \\
{[\mathbf{k W}]}\end{array}$ & $\begin{array}{c}\text { Air } \\
{[\mathbf{k W}]}\end{array}$ & $\begin{array}{c}\text { Sanitary water } \\
{[\mathbf{k W}]}\end{array}$ & $\begin{array}{c}\text { Total } \\
{[\mathbf{k W}]}\end{array}$ \\
\hline Main building & 512 & 420 & 80 & 1012 \\
\hline Closed pools & 32.3 & 63.6 & 130.5 & 226.4 \\
\hline $\begin{array}{c}\text { Geothermal pool (10x } \\
\text { 8)m }\end{array}$ & 18 & 35 & 72 & 125 \\
\hline $\begin{array}{c}\text { Sweet water pool } \\
(10 \times 5 \mathrm{~m})\end{array}$ & 11 & 22 & 45 & 78 \\
\hline Kids pool (5x3m) & 3.3 & 6.6 & 13.5 & 23.4 \\
\hline Subtotal & & & & $\mathbf{1 2 3 6 . 4}$ \\
\hline Closed pool (water) & & & & 68 \\
\hline Geothermal pool (water) & & & & 20 \\
\hline Sweet water pool (water) & & & & 1300 \\
\hline Olympic pool (water) & & & & $\mathbf{2 6 7 4 . 4}$ \\
\hline Total & & & & \\
\hline
\end{tabular}

TABLE 3: THE SUMMER THERMAL LOAD OF THE CENTER

\begin{tabular}{|c|c|c|c|c|}
\hline \multirow{2}{*}{ Room/environment } & \multicolumn{4}{|c|}{ SUMMER } \\
\cline { 2 - 5 } & $\begin{array}{c}\text { Thermal load } \\
{[\mathbf{k W}]}\end{array}$ & $\begin{array}{c}\text { Air } \\
{[\mathbf{k W}]}\end{array}$ & $\begin{array}{c}\text { Sanitary water } \\
{[\mathbf{k W}]}\end{array}$ & $\begin{array}{c}\text { Total } \\
{[\mathbf{k W}]}\end{array}$ \\
\hline Main building & 100 & 130 & 53 & 283 \\
\hline Closed pools & & & & 130.5 \\
\hline Geothermal pool (10x 8)m & & & & 72 \\
\hline Sweet water pool (10x5m) & & & & 13.5 \\
\hline Kids pool (5x3m) & & & & $\mathbf{4 1 3 . 5}$ \\
\hline Subtotal & & & & \\
\hline Closed pool (water) & & & & \\
\hline Geothermal pool (water) & & & & $\mathbf{4 1 3 . 5}$ \\
\hline Sweet water pool (water) & & & & \\
\hline Olympic pool (water) & & & & \\
\hline Total & & & & \\
\hline
\end{tabular}

TABLE 4: CLOSED POOLS ENVIRONMENT PARAMETERS

\begin{tabular}{|l|c|}
\hline Environment & Parameter \\
\hline \multirow{3}{*}{ Closed pools } & $\mathrm{V}_{\text {air }}=45\left[\mathrm{~m}^{3} / \mathrm{hm}^{2}\right]$ \\
\cline { 2 - 2 } & $\mathrm{Q}_{\text {floor }}=220\left[\mathrm{~W} / \mathrm{m}^{2}\right]$ \\
\cline { 2 - 2 } & $\mathrm{Q}_{\text {sanitary water }}=0.90\left[\mathrm{~kW} / \mathrm{m}^{2}\right]$ \\
\hline
\end{tabular}

\section{ECONOMICAL ANALYSIS}

In Table 5 is showed some costs data's related with the constructions cost for the Recreational Geothermal Center \& SPA, Shijon, and Elbasan. There can be clearly seen that the biggest investment should be done for the building $(66.7 \%)$, while that the total investment is calculated to be 5708285 Euro [6]. 
TABLE 5: COSTS CALCULATIONS FOR THE SHIJONI RECREATIONAL GEOTHERMAL CENTER \& SPA

\begin{tabular}{|c|c|}
\hline Constituent & Investment [€] \\
\hline Property (land) & 440880 \\
\hline Hotel-Clinic & 3808280 \\
$-\quad$ Building & 654560 \\
$-\quad$ Acclimatize system & 229670 \\
\hline$\quad$ Furniture & 186710 \\
\hline Greenhouse & 252085 \\
\hline Spirouline cultivation center & 136100 \\
\hline Acquaculture installations & 5708285 \\
\hline Total $[€]$ & \\
\hline
\end{tabular}

The economic analyses are done based on the Net Present Value (NPV) Calculations. The center will be constructed through a banking loan. Is underlined this fact, because the Albanian banking system do not give loan in such case if the Rate of Return (ROR) is lower than $0.1(10 \%)$. In the Table 6 are showed the NPV values for different scenarios, based in different Cash Flow (CF). From this table can be seen that the NPV become positive for CF greater than $350000 € / y$. In the "Fig. 4", is showed the chart of PV/time, while in the "Fig. 5", the chart of NPV/CF. Analytical analyses (and also graphical) shows that the NPV is equalized to zero, only if the CF is 382 $949 € / y$. For lower CF the NPV result negative and of course for greater $\mathrm{CF}$ it will be positive. The business plan predict a $\mathrm{CF}$ of about $445000 € / \mathrm{y}$, based in the Albanian touristic market and its prices [10].

TABLE 6: THE NPV CALCULATIONS FOR DIFFERENT SCENARIOS (BASED IN THE CF)

\begin{tabular}{|c|c|c|c|c|c|c|}
\hline \multirow{2}{*}{$\begin{array}{c}\text { Time } \\
\text { [years] }\end{array}$} & \multicolumn{6}{|c|}{ Present Value for different Cash Flow } \\
\hline & $250000[\epsilon / y]$ & $300000[\epsilon / y]$ & $350000[\epsilon / y]$ & $400000[\epsilon / y]$ & $450000[\epsilon / y]$ & $500000[\epsilon / y]$ \\
\hline 1 & $-5.09 \mathrm{E}+06$ & $-5.05 \mathrm{E}+06$ & $-5.00 \mathrm{E}+06$ & $-4.95 \mathrm{E}+06$ & $-4.91 \mathrm{E}+06$ & $-4.86 \mathrm{E}+06$ \\
\hline 2 & $-4.67 \mathrm{E}+06$ & $-4.58 \mathrm{E}+06$ & $-4.49 \mathrm{E}+06$ & $-4.40 \mathrm{E}+06$ & $-4.31 \mathrm{E}+06$ & $-4.22 \mathrm{E}+06$ \\
\hline 3 & $-4.32 \mathrm{E}+06$ & $4.19 \mathrm{E}+06$ & $-4.06 \mathrm{E}+06$ & $-3.93 \mathrm{E}+06$ & $-3.79 \mathrm{E}+06$ & $-3.66 \mathrm{E}+06$ \\
\hline 4 & $-4.01 \mathrm{E}+06$ & $-3.84 \mathrm{E}+06$ & $-3.67 \mathrm{E}+06$ & $-3.50 \mathrm{E}+06$ & $-3.33 \mathrm{E}+06$ & $-3.16 \mathrm{E}+06$ \\
\hline 5 & $-3.73 \mathrm{E}+06$ & $-3.52 \mathrm{E}+06$ & $-3.31 \mathrm{E}+06$ & $-3.10 \mathrm{E}+06$ & $-2.89 \mathrm{E}+06$ & $-2.68 \mathrm{E}+06$ \\
\hline 6 & $-3.46 \mathrm{E}+06$ & $-3.22 \mathrm{E}+06$ & $-2.97 \mathrm{E}+06$ & $-2.72 \mathrm{E}+06$ & $-2.48 \mathrm{E}+06$ & $-2.23 \mathrm{E}+06$ \\
\hline 7 & $-3.22 \mathrm{E}+06$ & $-2.93 \mathrm{E}+06$ & $-2.65 \mathrm{E}+06$ & $-2.36 \mathrm{E}+06$ & $-2.08 \mathrm{E}+06$ & $-1.79 \mathrm{E}+06$ \\
\hline 8 & $-2.98 \mathrm{E}+06$ & $-2.66 \mathrm{E}+06$ & $-2.34 \mathrm{E}+06$ & $-2.01 \mathrm{E}+06$ & $-1.69 \mathrm{E}+06$ & $-1.37 E+06$ \\
\hline 9 & $-2.75 \mathrm{E}+06$ & $-2.39 \mathrm{E}+06$ & $-2.03 \mathrm{E}+06$ & $-1.68 \mathrm{E}+06$ & $-1.32 \mathrm{E}+06$ & -959775 \\
\hline 10 & $-2.52 \mathrm{E}+06$ & $-2.13 \mathrm{E}+06$ & $-1.74 \mathrm{E}+06$ & $-1.34 \mathrm{E}+06$ & -950671 & -557274 \\
\hline 11 & $-2.31 \mathrm{E}+06$ & $-1.88 \mathrm{E}+06$ & $-1.45 \mathrm{E}+06$ & $-1.02 \mathrm{E}+06$ & -591445 & -162458 \\
\hline 12 & $-2.10 \mathrm{E}+06$ & $-1.63 \mathrm{E}+06$ & $-1.17 \mathrm{E}+06$ & .702794 & -238538 & 225717 \\
\hline 13 & $-1.89 \mathrm{E}+06$ & $-1.39 \mathrm{E}+06$ & $\begin{array}{l}-889616 \\
\end{array}$ & $\begin{array}{l}-390386 \\
\end{array}$ & 108844 & 608073 \\
\hline 14 & $-1.68 \mathrm{E}+06$ & $-1.15 \mathrm{E}+06$ & -616532 & \begin{tabular}{|l|}
-82596 \\
\end{tabular} & 451340 & 985275 \\
\hline 15 & $-1.48 \mathrm{E}+06$ & \begin{tabular}{|c|}
-915709 \\
\end{tabular} & -347315 & 221079 & 789472 & $1.36 \mathrm{E}+06$ \\
\hline 16 & $-1.29 \mathrm{E}+06$ & -684191 & -81569 & 521053 & $1.12 \mathrm{E}+06$ & $1.73 \mathrm{E}+06$ \\
\hline 17 & $-1.09 \mathrm{E}+06$ & -455596 & 181041 & 817677 & 1.45E+06 & $2.09 \mathrm{E}+06$ \\
\hline 18 & \begin{tabular}{|l|l|}
-900107 \\
\end{tabular} & -229656 & 440796 & $1.11 \mathrm{E}+06$ & $1.78 \mathrm{E}+06$ & $2.45 \mathrm{E}+06$ \\
\hline 19 & $\begin{array}{l}.710218 \\
\end{array}$ & $\begin{array}{l}-6140 \\
\end{array}$ & 697937 & 1.40E +06 & $2.11 \mathrm{E}+06$ & $2.81 \mathrm{E}+06$ \\
\hline 20 & -522379 & 215148 & 952675 & $1.69 \mathrm{E}+06$ & $2.43 \mathrm{E}+06$ & $3.17 \mathrm{E}+06$ \\
\hline 21 & $\begin{array}{l}-336429 \\
\end{array}$ & 434380 & $1.21 \mathrm{E}+06$ & $1.98 \mathrm{E}+06$ & $2.75 \mathrm{E}+06$ & 3.52E+06 \\
\hline 22 & -152225 & 651708 & $1.46 \mathrm{E}+06$ & $2.26 \mathrm{E}+06$ & $3.06 \mathrm{E}+06$ & $3.87 \mathrm{E}+06$ \\
\hline 23 & 30358 & 867264 & $1.70 \mathrm{E}+06$ & $2.54 \mathrm{E}+06$ & $3.38 \mathrm{E}+06$ & $4.22 \mathrm{E}+06$ \\
\hline 24 & 211429 & $1.08 \mathrm{E}+06$ & $1.95 \mathrm{E}+06$ & $2.82 \mathrm{E}+06$ & $3.69 \mathrm{E}+06$ & $4.56 \mathrm{E}+06$ \\
\hline 25 & 391087 & $1.29 \mathrm{E}+06$ & $2.20 \mathrm{E}+06$ & $3.10 \mathrm{E}+06$ & $4.00 \mathrm{E}+06$ & $4.90 \mathrm{E}+06$ \\
\hline 26 & 569420 & $1.50 \mathrm{E}+06$ & $2.44 \mathrm{E}+06$ & $3.37 \mathrm{E}+06$ & $4.31 \mathrm{E}+06$ & $5.24 \mathrm{E}+06$ \\
\hline 27 & 746506 & $1.71 \mathrm{E}+06$ & $2.68 \mathrm{E}+06$ & $3.65 \mathrm{E}+06$ & $4.62 \mathrm{E}+06$ & $5.58 \mathrm{E}+06$ \\
\hline 28 & 922416 & $1.92 \mathrm{E}+06$ & $2.92 \mathrm{E}+06$ & $3.92 \mathrm{E}+06$ & $4.92 E+06$ & $5.92 \mathrm{E}+06$ \\
\hline 29 & 1.10E+06 & $2.13 \mathrm{E}+06$ & $3.16 \mathrm{E}+06$ & $4.19 \mathrm{E}+06$ & $5.23 \mathrm{E}+06$ & $6.26 \mathrm{E}+06$ \\
\hline 30 & $1.27 \mathrm{E}+06$ & $2.34 \mathrm{E}+06$ & 3.40E+06 & $4.46 \mathrm{E}+06$ & $5.53 \mathrm{E}+06$ & $6.59 \mathrm{E}+06$ \\
\hline N.P.V & $-4.60 E+07$ & $-2.87 E+07$ & $-1.14 E+07$ & $5.87 \mathrm{E}+06$ & $2.32 \mathrm{E}+07$ & $4.04 \mathrm{E}+07$ \\
\hline
\end{tabular}

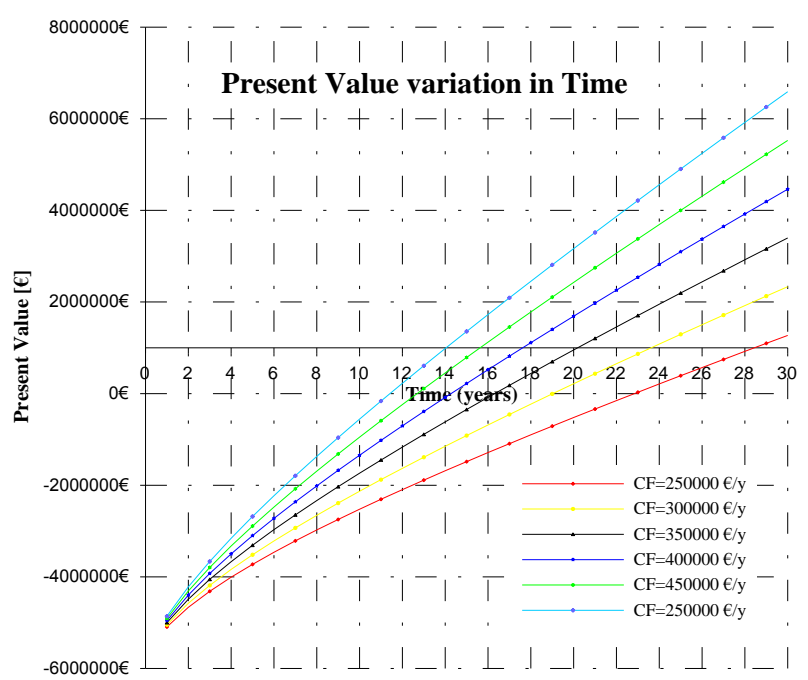

Fig.4. Present Value variation versus Time

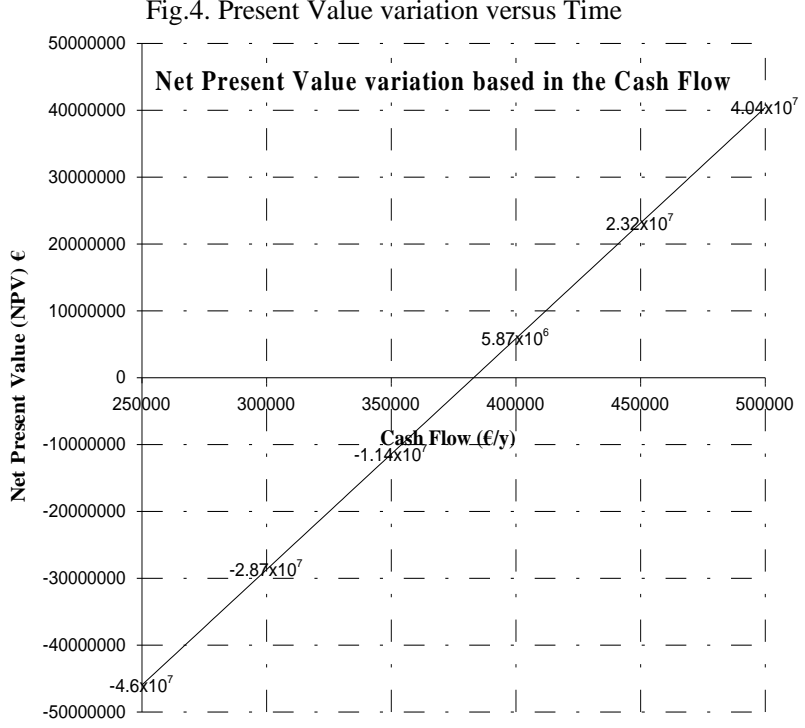

Fig.5. Net PRESENT VAlues FluCtuation Based on the CASH FLOW

Due to the investment value and also to the fact that this project-proposal is the first of its kind in Albania it was performed the risk analyses, using Palisade Decision Tool suite Industrial (Monte Carlo simulation). The results are showed in the "Fig. 6"\& "Fig. 7" [11].

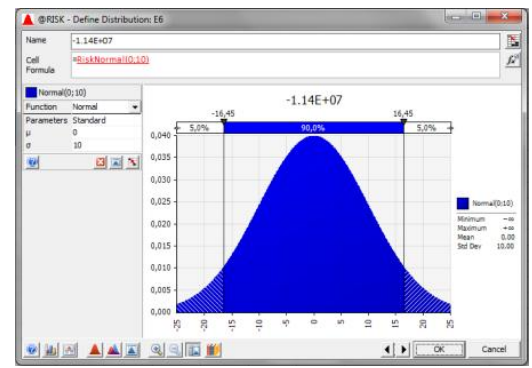

FIG.6. RISK ANALYSIS CHART FOR PV 350000 US\$/YEAR 


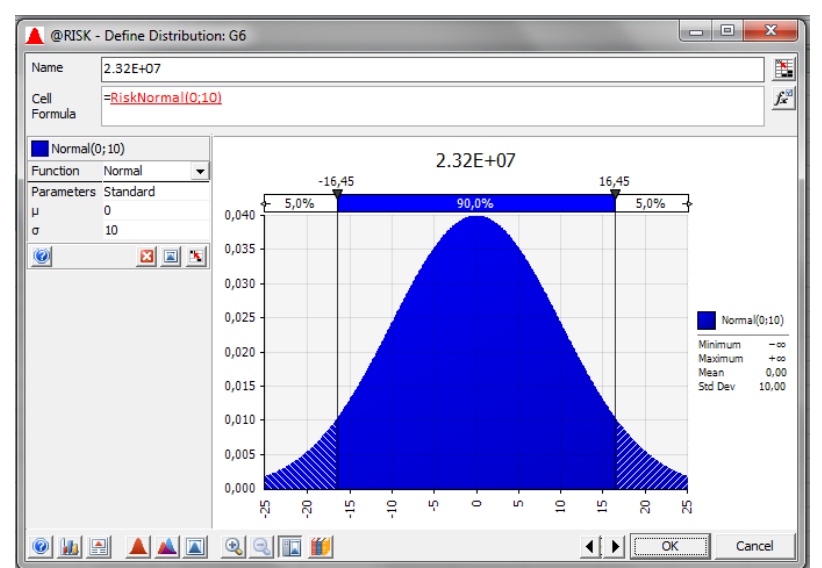

FIG.7. RISK ANALYSIS CHART FOR PV 450000 US\$/YEAR

The precision tree is showed in the "Fig. 8", this analysis prove that there is not any risk for the investment.

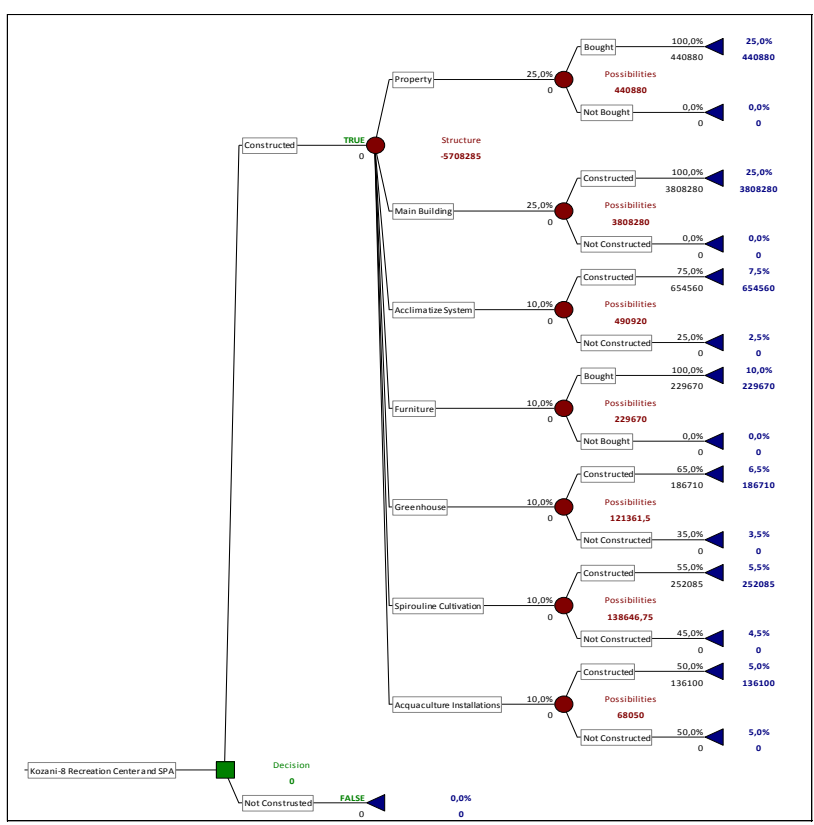

FIG.8. THE PRECISION TREE (USING MONTE CARLO SIMULATION)

\section{CONCLUSIONS}

1. The Kozani-8 water temperature is suitable for the supply of a recreational centre, including geothermal indoor and outdoor pools;

2. The water temperature is suitable for feeding of two cascades;

3. The hybrid system will improve the economic efficiency of the project;

4. The construction of the centre will improve the energetic balance of the region;

5. The construction of the centre will help on diversifying the energy resources in Albania;

6. The degasified and desalination line will improve the environmental status of the area, as actually is highly polluted;

7. It will improve the living standards of the community;

8. The economic analyses show that it is viable;
9. The risk analysis shows very optimistic data's for the future of the investment.

\section{ACKNOWLEDGMENT}

The authors wish to thank all the staff of the Energy Resources Department, the colleagues of the Faculty of Geology and Mining and their families for their support.

\section{REFERENCES}

[1]. Frashëri. A. and Čermak. V. 2004: The geothermal atlas of Albania. Sh. B. L. U. Tirana. 65-89.

[2]. Koçiaj. S. 1989: On the construction of the Earth Crust in Albania according to the first on set of "P" waves in the seismologic station. Bull. Of Geol. Sciences. 1. 400-410.

[3]. Aliaj. S. and Hyseni. A. 1996: The neotectonic map of Albania. Scale 1:200000. Sh. B. L. U. Tirana. 87 pp.

[4]. Harlow. J. H. \& Klapper. G. E. (1952): Residential Heat Pump Experiments in Philadelphia-Installation and Operating Experience. AIEE Trans 71/II. pp. 366-375. New York.

[5]. Hyseni. A. and Melo. V. 2000: The geodynamics of new movements in Albania and their influence in resources and environment. National programmer for research development. Toena. Tirana.

[6]. Frashëri. A., Kodhelaj. N., Albanian Geothermal Resources, platform in their utilization (Monograph). Klean, 2010, 184-193 pp.

[7]. Ingersoll. L. R. Adler. F. T. Plass. H. J. \&Ingersoll. A. C. (1950): Theory of Earth Heat Exchangers for the Heat Pump. ASHVE Trans. 56. 167-188.

[8]. Kodhelaj. N. 2011: Albanian possibilities on geothermal direct utilization. Renewable and sustainable energy review. Elsevier. 15/5. 2011. 2534-2544 pp.

[9]. Kodhelaj. N. 2007: The Llixha Elbasan hot springs in Albania. Study of temperature conditions and utilization calculations. Reports of the United Nations University. Geothermal Training Programmer in 2007. 157-199 pp.

[10]. Kodhelaj. N., Çela. B., Aleti. R., 2012: Kozani-8 Low Enthalpy Geothermal Water Use through a Cascade and Hybrid System, Study for Civil Engineering and Architecture, David Publishing House, USA, Volume 1, Issue 1, January 2013.

[11]. Albanian Low and Middle Enthalpy Geothermal Resources, Journal of Energy and Power Engineering, ISSN 1934-8975, USA, Volume 7, Issue 8, August 2013. 